\title{
FICUS ALONGENSIS (MORACEAE) RECOVERED AND REDEFINED
}

\author{
C.C. BERG \\ Bergen Museum, University of Bergen, Allégate 41, 5007 Bergen, Norway; \\ Nationaal Herbarium Nederland, Universiteit Leiden branch, P.O. Box 9514, \\ 2300 RA Leiden, The Netherlands; berg@nhn.leidenuniv.nl
}

\section{SUMMARY}

Ficus alongensis Gagnep. is reinstated and redefined.

Key words: Moraceae, Ficus, East Asia.

\section{INTRODUCTION}

During an abortive attempt to prepare the Moraceae for the English version of the Flora of China, which started with examination of material in the herbarium of Kunming (KUN), it became clear that among material referred to $F$. concinna Miq. (Miq.) (var. subsessilis Corner), F. maclellandii King, and F. microcarpa L.f. a poorly defined species was hidden. Further studies made it clear that this material matches more or less clearly the type of $F$. alongensis Gagnep. (1927), which has been reduced to a variety of $F$. superba Miq. with a note (Corner, 1960,1965) that it possibly represents a xerophytic state of $F$. superba var. japonica Miq. (Corner, 1960), which is currently included in F. subpisocarpa Gagnep. (see Berg \& Corner, 2005). One of the collections from Yunnan was identified as F. concinna var. subsessilis by Corner (1960), with a note "approaching $F$. cardiophylla", a taxon presently reduced to a subspecies of F. saxophila Blume (Berg, 2007). This gathering differs from material from eastern China, Vietnam, Laos, and Cambodia in a smooth upper surface of the thicker lamina, a difference that might be caused by occurrence at an altitude of c. $1600 \mathrm{~m}$, whereas the other collections are from lower altitudes.

Some specimens from Vietnam were identified as F. lacor Buch.-Ham., an erratically applied name, after lectotypification currently included in F. virens Aiton (see Berg, 2007).

Corner (1960) included in F. concinna var. subsessilis, F. subpedunculata Miq. (1867a: 217), which is not $F$. subpedunculata Miq. (1867b: 293), included in the synonymy of F. laevis Blume (see Berg \& Corner, 2005). The former name is linked to the group of predominantly ramiflorous species of sect. Urostigma, and in accordance with the description, pointing at early caducous basal bracts and included in F. concinna; the type of $F$. subpedunculata could not be traced, and therefore its identity is not quite certain.

Ficus alongensis differs from $F$. concinna in figs which do not occur on spurs on the older wood, but are placed axillary and/or just below the leaves and in the 


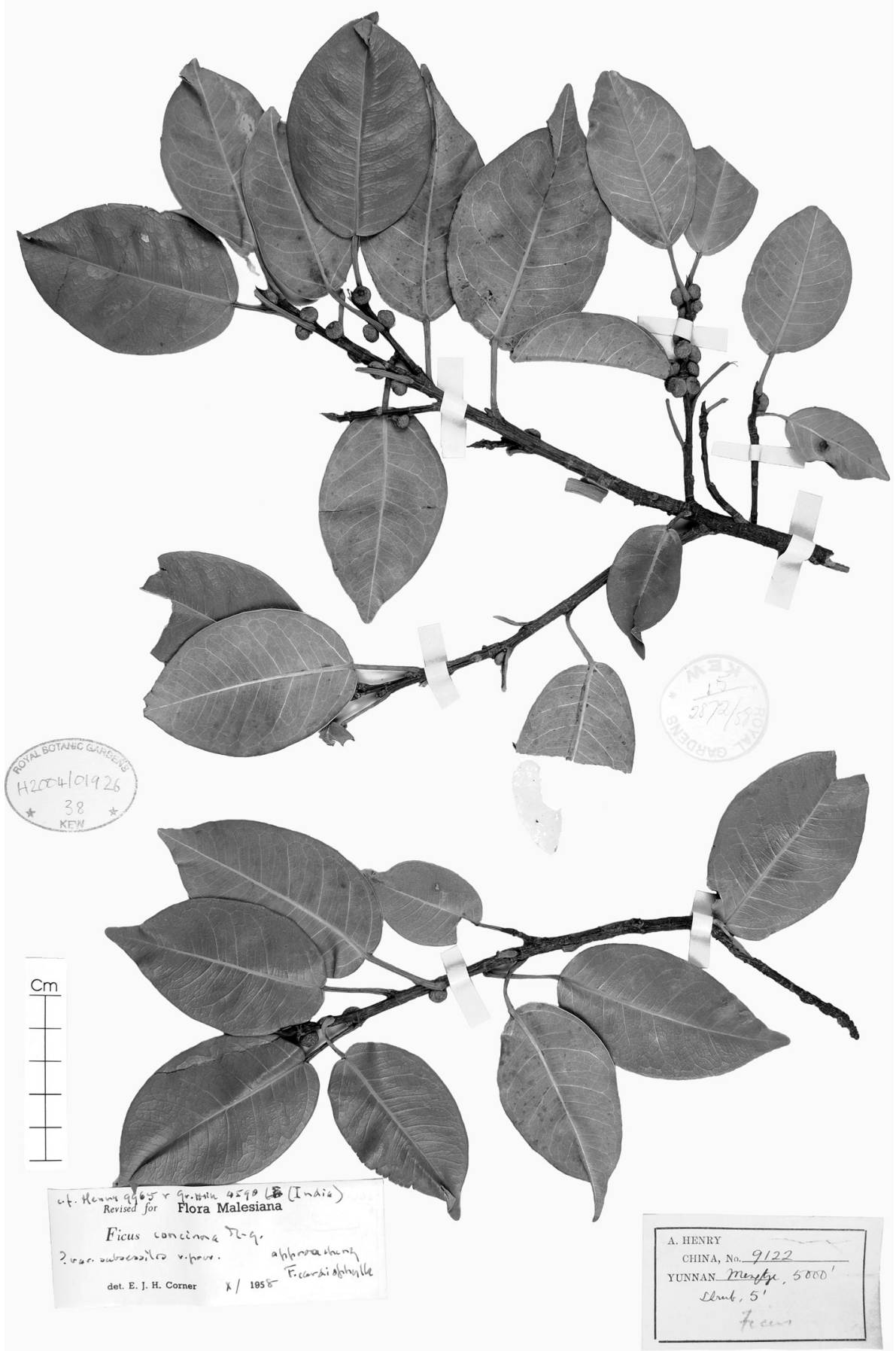

Fig. 1. Ficus alongensis Gagnep., Henry 9122 (K), China, Yunnan, 5000 ft. 


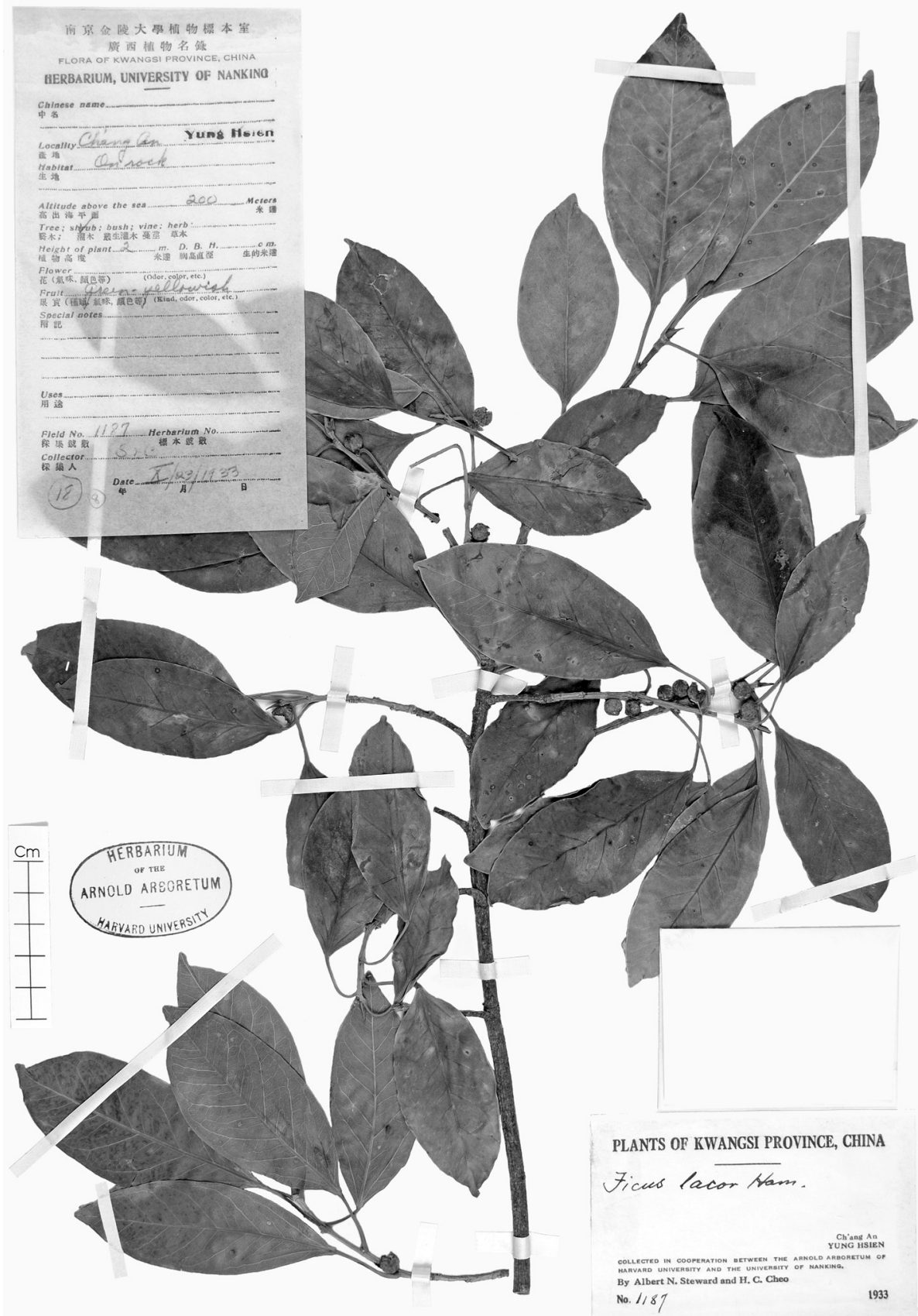

Fig. 2. Ficus alongensis Gagnep., Steward \& H.C. Cheo 1197 (A), China, Guangxi, 200 m. 


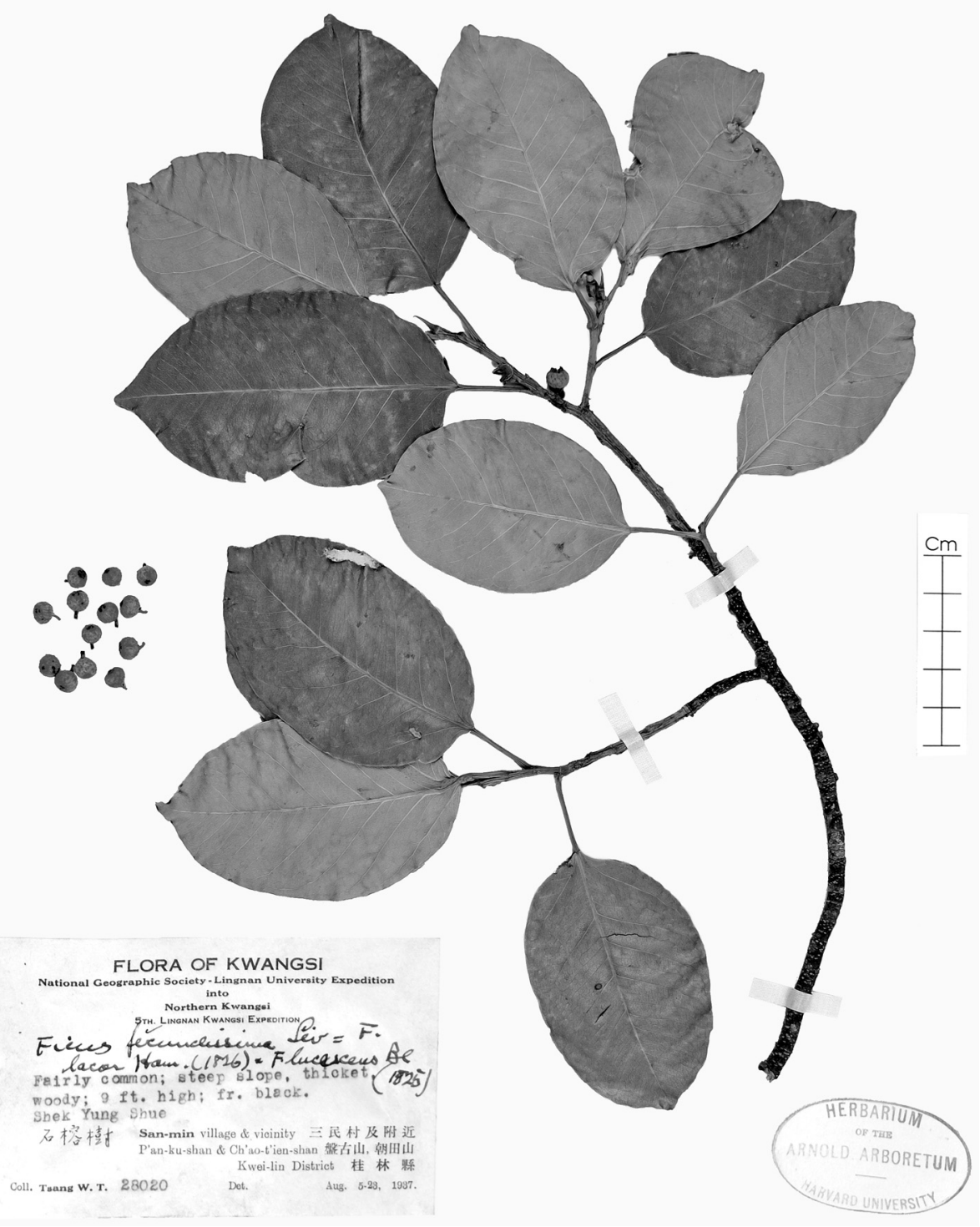

Fig. 3. Ficus alongensis Gagnep., W.T. Tsang 23020 (A), China, Guangxi.

persistent basal bracts. The species is rather variable in the shape of the lamina varying from elliptic to oblong to ovate (see Fig. 1-3). In the ovate lamina, the species shows similarities to F. saxophila subsp. cardiophylla (Merr.) C.C. Berg (2007), but differs in the more numerous lateral veins and the shorter basal lateral veins.

Ficus alongensis also varies in the length of the peduncle from 0 to $0.4 \mathrm{~cm}$. 
This species also shows over-all similarities to two species of subsect. Conosycea, $F$. benjamina and F. microphylla, which differ from it in the largely whitish ovaries and the disperse staminate flowers, and in the absence of clear indications of intermittent growth.

The material of $F$. alongensis shows intermittent growth, however, with only one or two short internodes marking the previous season's growth from new growth.

The distribution of the species cannot be defined with certainty. Most of the specimens currently included in the species are collected in SE China, Vietnam, Laos, and Cambodia. Occurrence in Thailand and NE India as stated by Corner (1960) could not yet be confirmed.

Ficus alongensis Gagnep. - Fig. 1-3

Ficus alongensis Gagnep. (1927) 84; (1928) 762. - Ficus superba (Miq.) Miq. var. alongensis (Gagnep.) Corner (1960) 376. - Type: Lecomte \& Finet 847 (holo P; iso P), Vietnam, 'baie d'Along, île aux Biches', 8 Sept. 1911.

Ficus concinna (Miq.) Miq. var. subsessilis Corner (1960) 376. - Type: Ching 1917 (holo K), China, Zhejiang, Pingyang, 21 June 1924.

Tree up to 12(-30) $\mathrm{m}$ tall or shrub, with intermittent growth. Branches brown to blackish. Leafy twigs $1.5-4 \mathrm{~mm}$ thick, slightly angular to subterete, glabrous; periderm persistent. Leaves spirally arranged, coriaceous, oblong to elliptic to (sub)ovate, (2.5-)5-12 by (1-)1.5-5(-6) $\mathrm{cm}$, apex (short-)acuminate (with the acumen obtuse) to obtuse (to rounded or subtruncate), base obtuse to rounded or subcordate, margin entire; upper and lower surface glabrous, smooth; cystoliths only beneath; midrib flat above, lateral veins (5-)6-10 pairs, the basal pair up to $1 / 5-1 / 4(-1 / 3)$ the length of the lamina, unbranched (or in ovate laminas branched), the other lateral veins furcate away from the margin, tertiary venation largely parallel to the lateral veins to partly reticulate, the reticulum \pm prominent and clearly visible above and beneath (or flat); waxy gland at the base of the midrib beneath; petiole $1.2-3(-5) \mathrm{cm}$ long, c. $1 \mathrm{~mm}$ thick, widely canaliculate, glabrous, the epidermis persistent; stipules $0.5-1(-3) \mathrm{cm}$ long, glabrous, caducous. Figs axillary or also below the leaves on previous season's growth, in pairs or solitary; subsessile or with a peduncle up to 2(-4) mm long, basal bracts 1-2 mm long, persistent; receptacle subglobose to depressed-globose, $0.5-0.7 \mathrm{~cm}$ diam. when dry, glabrous, usually \pm maculate, colours at maturity unknown, apex of receptacle convex; ostiole c. $1.5 \mathrm{~mm}$ diam., \pm prominent, closed by glabrous bracts; internal hairs absent. Staminate flowers ostiolar. Tepals reddish. Ovary (dark) red-brown.

Distribution - NE India (?), Thailand (?), China (Zhejian, Jiangxi, Guangxi, Guangdong (incl. Macao), Hongkong, and Yunnan), Laos, Vietnam, Cambodia.

Habitat - Forest at low altitudes, in Yunnan between 1100 and $1600 \mathrm{~m}$.

\section{ACKNOWLEDGEMENTS}

Some of the data for this study have been acquired during a visit to herbarium E(dinburgh), financed by the European Commission's Research Infrastructure Action via the SYNTHESYS Project. 


\section{REFERENCES}

Berg, C.C. 2007. Precursory taxonomic studies on Ficus (Moraceae) for the Flora of Thailand. Thai Forest Bull., Bot. 35: 4-28.

Berg, C.C. \& E. J.H. Corner. 2005. Moraceae - Ficus. Flora Malesiana, Ser. I, 17/2. Leiden.

Corner, E.J.H. 1960. Taxonomic notes on Ficus Linn., Asia and Australasia. I. Subg. Urostigma (Gasp.) Miq. Gard. Bull. Singapore 17: 368-404.

Corner, E.J.H. 1965. Check-list of Ficus in Asia and Australasia with keys to identification. Gard. Bull. Straits Settlem. 21: 1-186.

Gagnepain, F. 1927. Espèces nouvelles de Ficus. Notul. Syst. (Paris) 4: 84-98.

Gagnepain, F. 1928-1929. Moraceae. In: M.H. Lecomte, Flore Générale de Indo-Chine 5: 694828.

Miquel, F.A.W. 1867a. Artocarpeae. Ann. Mus. Bot. Lugduno Batavi 3: 210-235.

Miquel, F. A.W. 1867b. Annotationes de Ficus speciebus. Ann. Mus. Bot. Lugduno Batavi 3: 60300 . 